\title{
The Future of Fashion Technology \& Textile Engineering
}

\author{
Lorraine Justice* \\ Department of Design, Dean Emerita, Rochester Institute of Technology, United States
}

Submission: March 27, 2018; Published: April 05, 2018

*Corresponding author: Lorraine Justice, Department of Design, Dean Emerita, Rochester Institute of Technology, College of Imaging Arts and Sciences, United States, Email: Lorraine.justice@rit.edu

\begin{abstract}
The future of fashion technology and textile engineering will involve much more than the latest technological advances. It will require that designers and technologists also have an understanding of important social and cultural issues, increased knowledge of sustainability, and an increasing empathy for user needs.
\end{abstract}

Keywords: : Design; Design and Technology; Design for the Future; Sustainability; Social and Cultural Issues

\section{Introduction}

There was a time when what mattered most in fashion and textile design (and all design) was the aesthetic and sales potential. If the aesthetic was right it would have impact on the field, which would lead to higher sales and higher brand value. Times are changing however, for all designers. The work of designing fashion and textiles is expanding, largely due to consumer demand that stretches beyond the aesthetic and sales potential. Designers and technologists will find their roles expanding due to increased consumer demands, newly emerging technologies, and societal and cultural issues.

\section{Consumer demands}

Consumers today are more aware than in the past of many aspects of their clothing or textile products. Due to social media, and company transparency, consumers can learn where their products are made, by whom, in which region or country, and if the company is ethical and giving back to the region. One company who manufactures sweaters provides information on the sheep that contributed, and how you can track them in the pasturelands in South America. Consumers can learn if the company is following rules for sustainability and recyclability of any products made, or waste generated. So, consumers in the past were glad to have their fashion and textiles "speak for them" in relation to communicating a mood or personality. Today, however, many consumers want their fashion and textile brands to reflect the consumer's values as well.

Fashion and textile designers today need to be aware of social and cultural issues in relation to what they are designing and for whom. Sensitivity to religions, cultural practices, and societal issues has become one of the top skills needed for all designers, if they are designing for users of their products and brands. This is not to be confused with artists who will want to communicate what they believe is important, or to make a statement about society.

\section{Technology demands}

The innovation of new materials, new designing software, new body scanning equipment, 3-D printing, and sensor enriched textiles are only some of the new technologies emerging today. The new technologies will help all design fields to innovate for new and improved clothing and textiles. Designers, however, will need to spend precious time keeping up with the new technologies just to see if they can be incorporated into their work. The new technologies will open up new types of fashion and clothing for all categories. Medicine and textiles will take a major leap, along with the innovations for clothes that keep us safe, dry, hot or cold, or locate us, if needed.

\section{Societal and cultural demands}

Social media has had a great effect on public opinion. We can easily track trends, what certain cultures feel is right or wrong, or learn about something as specific as the impression of a piece of clothing (hoodies, yoga pants, flannel shirts, etc.). Designers today need to be more aware then ever of what is currently in demand, not wanted, or considered offensive. If they are designing for a foreign country or region, they will need to do extensive information-finding before they start the design process. You may not be able to rely on the internet for all of your information but may need to engage with someone from the region in which you are trying to sell. These discussions can 
help the designer to uncover opportunities they might not have found just searching the web.

\section{Conclusion}

The role of the fashion and textile designers will grow exponentially as the consumer demands increase, the technology and innovations continue to grow, and the complexity of the different regions of the world become a part of the knowledge we need in order to design. Universities and art schools that support fashion and textile programs will need to update their curricula, inform their students of changes in the field, and provide them with opportunities to learn the latest technologies (hardware and software).
New areas of fashion and textile design will open up. Engagement with specialists for technologists, design researchers, sociologists and sustainability experts will begin to be a normal part of a team. While it may seem that more work is being added to an already difficult position, it is conceivable that these new demands can move us into an even greater era of fashion and textile design.

\section{Acknowledgement}

A thank you to Hachette Publishing who will release in the spring of 2019 The Future of Design, Creating innovative products in a complex world, by Lorraine Justice.

\section{Your next submission with Juniper Publishers will reach you the below assets}

- Quality Editorial service

- Swift Peer Review

- Reprints availability

- E-prints Service

- Manuscript Podcast for convenient understanding

- Global attainment for your research

- Manuscript accessibility in different formats

( Pdf, E-pub, Full Text, Audio)

- Unceasing customer service

Track the below URL for one-step submission https://juniperpublishers.com/online-submission.php 